\title{
The Extended Shopping Experience of Used Clothes in Hungary
}

\author{
Kata Kapusy ${ }^{1 *}$, Emma Lógó1 \\ 1 Department of Ergonomics and Psychology, Faculty of Economic and Social Sciences, Budapest University of Technology and \\ Economics, H-1117 Budapest, P. O. B. 91, Hungary \\ * Corresponding author, e-mail: kapusykata@erg.bme.hu
}

Received: 17 April 2019, Accepted: 30 May 2019, Published online: 10 June 2020

\begin{abstract}
Nowadays, the accepted economic theory is that consumer behaviour needs to be considered not only for its physical elements but also for its emotional aspects. The service economy has turned into an experience-based economy, and supply is based on a consumer's experience, specializing in gaining experience. Product experience has three aspects, namely, consumers' thoughts, values, and perceptions about the product. Shopping experience involves consumer processes and responses to the shopping environment, situation, and consumer characteristics. In this article, the concepts of product and shopping experience are examined for whether they are related and if so, how. The topic was examined through the purchase of second-hand clothes, because on the one hand, it is a very important environmental issue, and on the other hand purchase of the product recalls a very similar in-store shopping environment in Hungarian people. Qualitative processing of a questionnaire $(n=1060)$ gave the answer to what the connection between product and shopping experience is, and values derived from the extended shopping experience of used clothes are shown in the FioreOgle model. The results highlight some relevant aspects of used clothes shopping in Hungary and deliver recommendations on how sustainable consumption and environmental consciousness could be strengthened.
\end{abstract}

Keywords

shopping experience, product experience, second-hand clothes, qualitative research

\section{Introduction}

Nowadays, second-hand clothes have become increasingly widespread in global fashion trends, and research is gaining much more attention from their understanding of the phenomenon. Resale, including used clothing, used furniture, antiques, and vintage items, is a multibillion-dollar industry. Fashion and eco-friendliness seem to be conflicting concepts; thus, it follows that sustainable fashion is often described as an oxymoron: fashion assumes products with short lifecycles, which contrasts with the long-term perspective of sustainability and usage of the re-use of products (Henninger et al., 2016). Consumers seem to be more and more concerned with the impact of the production of clothes on their health, the environment and society at large, an eco-fashion movement has emerged (Cervellon and Carey, 2011). The term second-hand categorizes any piece of clothing which has been used before (Cervellon et al., 2012). Consumers are increasingly more engaged in recycling or donating their used clothes (Ha-Brookshire and Hodges, 2009) because this process is considered as an effective way to reduce waste and impact positively on the environment (Bianchi and Birtwistle, 2010).

Clothing provides a unique consumption experience for consumers, because it is consumed by everyone every day, and could be stored away and not merely used once - unlike others (Ha-Brookshire and Hodges, 2009). From this perspective, clothing consumption is much more complicated, providing a wider range of different stages. Globally the wholesale used clothing trade is valued at more than $£ 4$ bn. Fig. 1 shows that the formerly fast-growing used clothing import/export business has declined over the past few years.

According to Gittleson (2018), Hungary was ninth for the most used clothes imports of the world in 2016. Therefore, it seems as if in Hungary, second-hand clothes' consumption is widespread. 


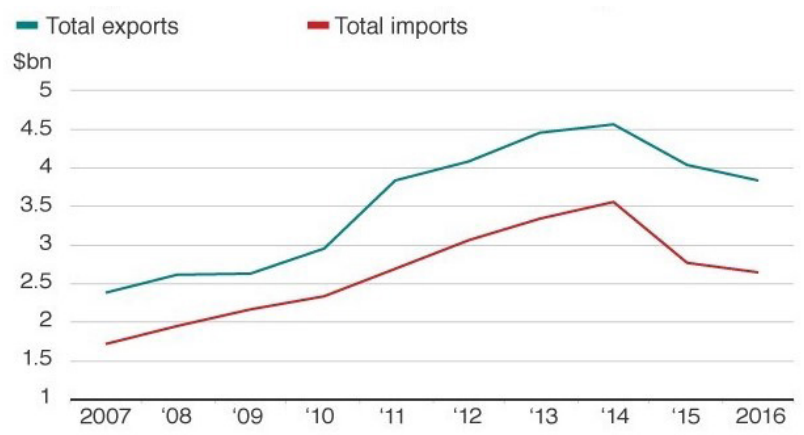

Fig. 1 Total global used clothing trade by value, source: Gittleson (2018)

\subsection{Extended shopping experience}

Nowadays the accepted economic theory is that consumer behaviour needs to be considered not only for its physical elements, but also for its emotional aspects, and the service economy has turned into an experience-based economy and supply is based on a consumer's experience, specializing in gaining experience (Pine and Gilmore, 1999). The current focus is on the consumer while the business strategy revolves around experience research. While service research and practice focused on service quality and satisfaction in the 1980s and 1990s, from the 2000s onwards, customer experience analysis and maximization became central issues. The first important aspect is that services have become very complicated, each service having become a service system experience. The second important factor is multichannel customer access, which applies to the entire consumer journey, from demand to behaviour after purchase (Rangaswamy and Van Bruggen, 2005).

There is a wide range of experience research, depending on which player is at the centre of attention during the consumer journey. Human-product interaction and product experience are closely interwoven concepts (Hlédik and Lógó, 2017). Product experience focuses on the understanding of people's subjective experiences that result from interacting with products. According to Schifferstein and Hekkert (2008) the psychological effects elicited by the interaction with a product, includes all our senses being stimulated, the meanings and values we attach to product, and the feelings and emotions that are elicited. Interaction is intertwined with subjective experience with the product, moreover, Marshall (1995) - in his book called Food and Consumer choice-, based on earlier cross-cultural research states that product experience is different at each stage of the provisioning process and habit has a major role to play in this also. According to (King et al., 2004) and Boutrolle et al. (2005), research products seem to be experienced differently in different contexts. The shopping environment affects customers' perception, according to Berčík et al. (2016), on the type of merchandised goods, and it is necessary to adjust the music in order to create a pleasant atmosphere. Although research on environmental or contextual variables has been done and there are a number of reviews Meiselman (1996) and Stroebele and De Castro (2004), and there is still no comprehensive and integrated view of which environmental variables are critical, and how they operate to produce product experience.

In our research, the other focus was shopping experience, which is also part of customer experience, and its concept was created by Fiore and Ogle (2000), and it was developed by Fiore (2008). It involves consumer processes (e.g., product evaluation) and responses (e.g., satisfaction, enjoyment, or purchase behaviour) affected by aspects of the shopping environment, situation, and consumer characteristics. It has a strong collocation with product experience, which includes what consumers feel, a sense or knowledge about the product (Schifferstein and Hekkert, 2008). According to these definitions, the relation of product and shopping experience concepts could be summarized in Fig. 2.

The consumer's rational assessment of a product's quality, which leads to product purchase, has been complemented with the effects of the shopping environment on hedonic aspects of experience and consumer behaviour. Holbrook states that beyond the shopping experience, there are relevant values that are added to consumption experiences (Holbrook, 1996). According to Fiore and Ogle (2008), the values derived from shopping experiences cause experiences that are non-instrumental but rewarding and pleasurable in and of themselves and utilitarian benefits that help one attain external aims or goals such as social or economic gain. Fiore and Ogle (2008) organized benefits according to their emphasis on formal (sensory), expressive, and symbolic qualities. We have reversed the Fiore-Ogle model as Fig. 3 shows, in order to

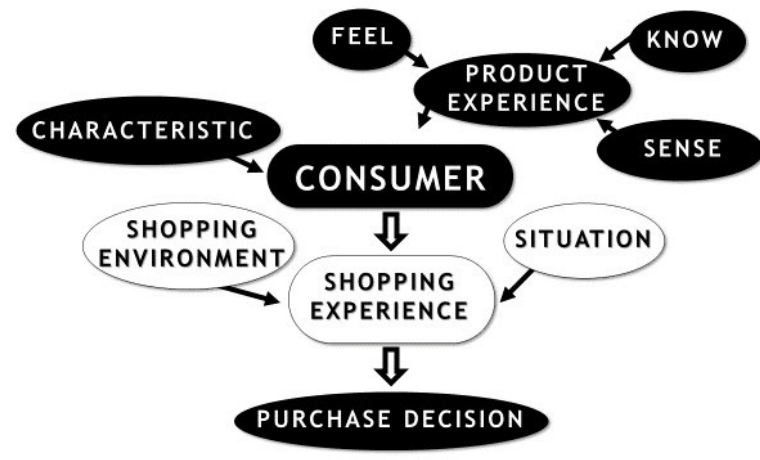

Fig. 2 Extended shopping experience, source: own compilation 


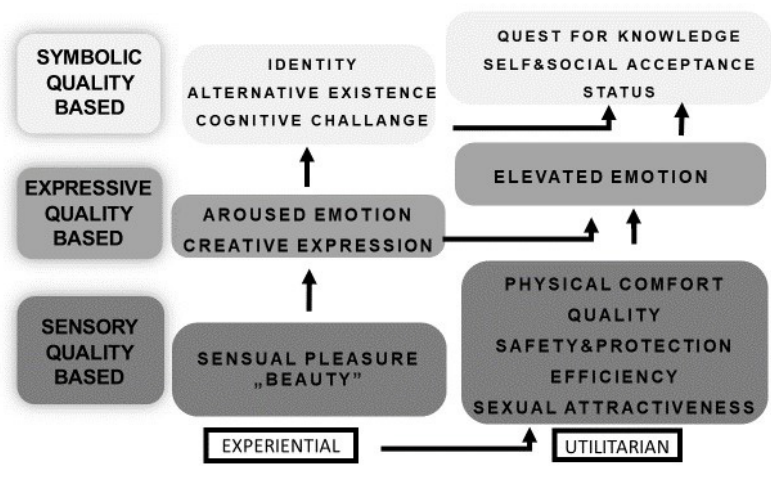

Fig. 3 Shopping experience based on Fiore-Ogle model (2008), source: own compilation (Fiore and Ogle, 2008)

follow the logic of the Maslow hierarchy of needs in our case benefits ("deficiency needs"), which are basic physical requirements are in the bottom of the pyramid, and they are called sensory quality-based benefits. The next level concludes the benefits expressing emotions.

The highest level includes symbolic quality-based benefits, which usually correspond with non-product related attributes and relate to underlying needs for social approval or personal expression and outer-directed self-esteem. This level matches Maslow' s "growth" needs. The FioreOgle model does not entertain negative experiences.

\section{Methodology}

Our research focused on the shopping experience of second-hand clothes. Our first aim was to confirm whether our model according to the product and shopping experience literature, is valid. Then we analysed what kind of positive and negative experiences are realized in the shopping experience of used-clothes, and these were integrated into the Fiore-Ogle Model.

Our methodology is based on two steps. First, with the help of a questionnaire, the main experiences of second-hand clothes shopping were explored. Results were construed and classified. Received categories were compared to our extended shopping experience model which was based on the concepts of product and shopping experience definitions. In the second phase received negative, positive experiences with their frequencies were integrated in Fiore-Ogle model.

\subsection{Qualitative method}

The questionnaire was conducted on 1,060 people, out of which were 115 Baby boomers (born between 1940-1959), 251 X Generation (born between 1960-1979), 453 Y Generation (born between 1980-1995) and 241
Z Generation (born between 1996-2009). There were 881 female and 179 male respondents. All participants were Hungarian: 647 from the capital city Budapest, 368 from outside of the capital and 45 people, who live abroad. All of them were unaware of the purpose of the study. An online anonymous questionnaire was used and distributed on different social media websites between 01/12/2018 and 15/01/2019. The data were non representative. They were asked to answer the following two questions:

- If you think of buying second-hand clothes, what your first thoughts are?

- Please tell us what you think of buying used clothes?

\subsection{Results 1}

Each answer had several sentences, thoughts about the shopping of second-hand clothes (see Fig. 4). Overall, three main aspects were discovered:

- Negative experiences: unpleasant feelings, circumstances, facts.

- Positive experiences: facts, values, perceptions which caused joy, pleasant feelings.

- Memories: helped respondents remember.

This last aspect could have appeared because according to Munkácsi (2018), in the purchase situation, consumers actively recall memories of previous personal experiences.

The essentials of answers were determined and categorized. Six main groups were classified: product, price, feeling, shopping environment, situation, society. Each of them has subcategories. Product group refers comments for the quality, uniqueness, its origin and how trendy the clothes are. Price is connected to product, but it became an independent category, because many comments arrived from this. Another main category is society, which includes two approaches: either used-clothes shopping is collocated with poverty or

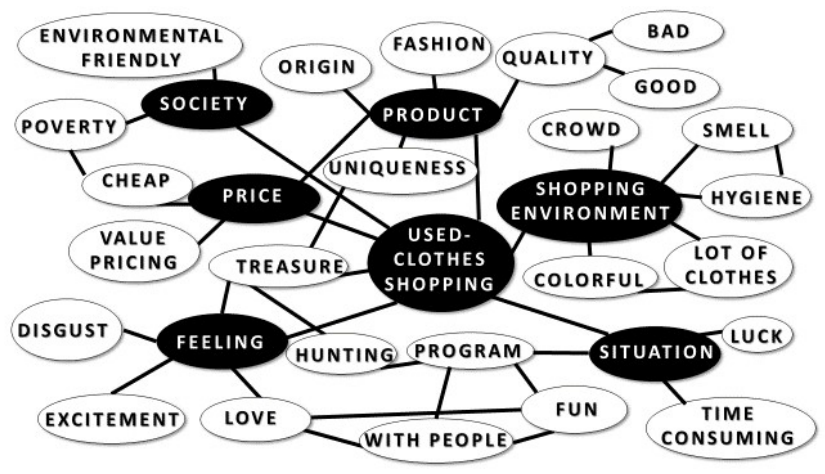

Fig. 4 Mindmap from the received data, source: own compilation 
with environmental-friendliness. Respondents shared emotions too. The experience is full of excitement or joy, and the clothes bought are valued as treasures.

The situation is the fifth main category: it demands time and luck, and it is considered as an adventure. It could be a fun experience, sometimes with friends, for some people, it feels like hunting. The shopping environment is the last main category. People evoke memories according to smell, hygiene, perception of a lot of clothes, the sensory pleasure of many colours. Categories were also valued as they were positive, negative, or neutral. Summarizing every comment, Table 1 shows the received statistics.

Nearly all of the respondents gave comments referring to the product: beliefs, or previous experiences with used clothes. Many people mentioned that this purchase is value pricing. Another significant amount of comments expressed feelings: 106 negative, 82 neutrals, and 480 (e.g., joy, excitement) positive emotions were mentioned. Shopping environment comments referred to the wide variety of clothes, visual effects of the environment (e.g., colourful), also evoked memories, how crowded could be a certain shop, and most of them (145) referred to the special smell of used clothes shops though mainly with negative collocations. Respondents mentioned that buying second-hand clothes is an event or an adventure. The last great amount of remarks was given to the social effect: 89 referred to the fact that buying second-hand clothes indicates poverty, and 207 comments highlighted the importance of recycling. Most remarks mentioned second-hand clothes purchase with positive collocations.

According to our results, extended shopping experience included aspects, as can be seen in Fig. 5.

It means that our respondents when thinking about buying used clothes, evoke memories of the product itself, its price and how they feel about it, and also about the shopping experience and what the circumstances are of it. Society trends and beliefs seem to influence consumers too.

\subsection{Results 2}

In the second phase, subcategories were interpreted with values derived from the shopping experience. In contrast with the Fiore-Ogle model in our results, negative experiences were also declared. The frequency of their occurrence can be seen in Table 2.

Table 1 Frequencies of main categories, source: own compilation

\begin{tabular}{ccccccc}
\hline & Product & Prize & Feeling & $\begin{array}{c}\text { Shopping } \\
\text { environment }\end{array}$ & Situation & Society \\
\hline sum & 1421 & 889 & 502 & 514 & 575 & 297 \\
\hline
\end{tabular}

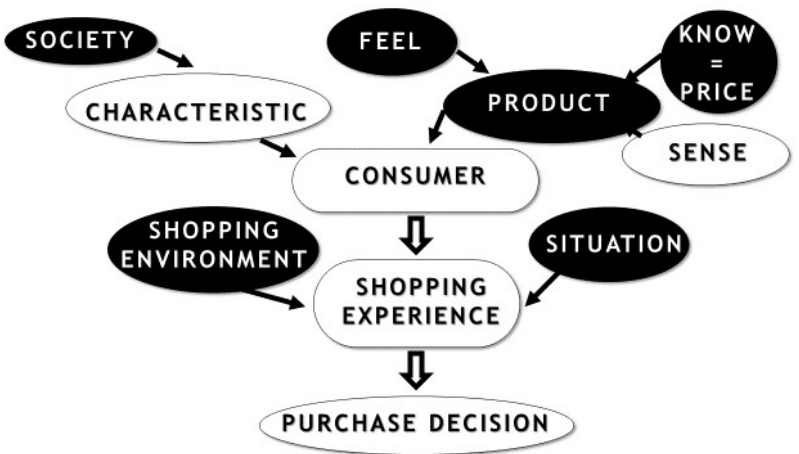

Fig. 5 Extended shopping experience of second-hand clothes, source: own compilation

Respondents evoked memories like how colourful and dirty second-hand clothes could be in-store shop. $14 \%$ of them revealed the smell of it, which is consonant with Willander and Larsson (2006) findings that odour evoking memories produced a stronger feeling in time than visual ones. One of the sensory-based values on the utilitarian side is efficiency. Price was mentioned by the majority ( $71 \%$ ) of respondents, moreover that this is a value-pricing and time-consuming shopping form. Remarks concerned quality whether it is good (24\%) or bad $(20 \%)$. A crowd in a shopping environment caused in $4 \%$ of them negative experiences. $35 \%$ of them could express and feel their creativity through the uniqueness of second-hand clothes. Respondents aroused feeling of happiness (19\%) and of disgust (7\%) and also elevated emotions like being lucky, excited. Symbolic quality based values could hardly be defined, so only three aspects appeared: alternative existence, status, self and social acceptance. Noticeable collocations are poverty (7\%) and its environmental-friendly effect (20\%).

\section{Conclusion}

Our findings that product experience has a strong collocation with the shopping experience and both plays very important role in purchase decision. In the process of the second-hand, clothes purchase shopping environment, customers' previous experience with the product, the situation, and also society play important roles. In order to offer positive experiences for the customers, the in-store shopping environment of second-hand clothes sensory-based quality benefits should be gratified by colourfully, scented, and well-organized environments and clothes. The "attitude/behaviour gap" or "values/action gap" is where $30 \%$ of consumers report that they are very concerned about environmental issues (Young et al., 2009). Still, they are struggling to translate this into purchases, 
Table 2 Subcategories interpreted with values derived from the shopping experience, source: own compilation

\begin{tabular}{|c|c|c|c|}
\hline IDENTITY & - & QUEST FOR KNOWLEDGE & - \\
\hline ALTERNATIVE EXISTENCE & $\begin{array}{l}\text { FINDING CLOTHES } 13 \% \\
\text { TOO MANY PRODUCTS } 4 \%\end{array}$ & SOCIAL ACCEPTANCE & $\begin{array}{l}\text { ADVENTURE } 11 \% \\
\text { FASHION } 11 \% \\
\text { NOT TRENDY } 3 \%\end{array}$ \\
\hline COGNITIVE CHALLENGE & - & SELF ACCEPTANCE & ENVIRONMENTAL-FRIENDLY $20 \%$ \\
\hline AROUSED EMOTION & $\begin{array}{l}\text { POSITIVE FEELING } 19 \% \\
\text { DISGUST } 7 \%\end{array}$ & STATUS & POVERTY $7 \%$ \\
\hline CREATIVE EXPRESSION & UNIQUENESS $35 \%$ & ELEVATED EMOTION & $\begin{array}{c}\text { FINDING TREASURE } 9 \% \\
\text { LUCK } 16 \% \\
\text { EXCITEMENT } 7 \% \\
\text { FEELS LIKE HUNTING } 5 \%\end{array}$ \\
\hline \multirow[t]{2}{*}{ SENSUAL PLEASURE } & \multirow[t]{2}{*}{ SMELL $14 \%$} & $\begin{array}{c}\text { PSHYSICAL COMFORT } \\
\text { QUALITY }\end{array}$ & $\begin{array}{c}\text { CROWD } 4 \% \\
\text { GOOD QUALITY } 24 \% \\
\text { BAD QUALITY } 20 \%\end{array}$ \\
\hline & & SAFETY and PROTECTION & - \\
\hline \multirow[t]{2}{*}{ "BEAUTY" } & \multirow[t]{2}{*}{$\begin{array}{l}\text { COLOURFUL INSIDE } 6 \% \\
\text { DIRTY ENVIRONMENT } 6 \%\end{array}$} & EFFICIENCY & $\begin{array}{c}\text { PRICE } 71 \% \\
\text { TIME-CONSUMING } 15 \% \\
\text { VALUE-PRICING } 11 \%\end{array}$ \\
\hline & & SEXUAL ATTRACTIVENESS & TO BE TRENDY $7 \%$ \\
\hline
\end{tabular}

so this could be a solution for them, and consumers should be educated about the environmental protection effect of this consumption. In marketing messages, the following topics should be in focus:

- It is trendy,

- It does not mean poverty,

- It feels like hunting,

- It could be a fun adventure with friends,

- Treasures like unique clothes could be found.

\section{References}

Berčík, J., Horská, E., Gálová, J., Margianti, E. S. (2016) "Consumer Neuroscience in Practice: The Impact of Store Atmosphere on Consumer Behavior", Periodica Polytechnica Social and Management Sciences, 24(2), pp. 96-101.

https://doi.org/10.3311/PPso.8715

Bianchi, C., Birtwistle, G. (2010) "Sell, give away, or donate: An exploratory study of fashion clothing disposal behaviour in two countries", International Review of Retail, Distribution and Consumer Research, 20(3), pp. 353-368.

https://doi.org/10.1080/09593969.2010.491213

Boutrolle, I., Arranz, D., Rogeaux, M., Delarue, J. (2005) "Comparing central location test and home use test results: Application of a new criterion", Food Quality and Preference, 16(8), pp. 704-713. https://doi.org/10.1016/j.foodqual.2005.03.015

Cervellon, M.-C., Carey, L. (2011) "Consumers' perceptions of 'green': Why and how consumers use eco-fashion and green beauty products", Critical Studies in Fashion and Beauty, 2(1-2), pp. 117-138. https://doi.org/10.1386/csfb.2.1-2.117_1
To conclude, we might assert that revealing and measuring consumer experience should be dealt with in a holistic approach because it includes product and shopping experiences too. Understanding all aspects of experiences can help shop managers build more effective strategies.

\section{Acknowledgement}

The project presented in this article is supported by Új Nemzeti Kiválóság Program.

Cervellon, M.-C., Carey, L., Harms, T. (2012) "Something old, something used: Determinants of women's purchase of vintage fashion vs second-hand fashion", International Journal of Retail and Distribution Management, 40(12), pp. 956-974. https://doi.org/10.1108/09590551211274946

Fiore, A. M., Ogle, J. (2000) "Facilitating Students' Integration of Textiles and Clothing Subject Matter Part One: Dimensions of a Model and a Taxonomy", Clothing and Textiles Research Journal, 18(1), pp. 31-45. https://oi.org/10.1177/0887302X0001800104

Fiore, A. M. (2008) "The Shopping Experience", In: Schifferstein, H. N. J., Hekkert, P. (eds.) Product Experience, Elsevier, Oxford, UK, pp. 629-645.

https://doi.org/10.1016/B978-008045089-6.50030-7

Gittleson, K. (2018) "Used clothes: Why is worldwide demand declining?", BBC News, [online] 31 January 2018. Available: at: https://www. bbc.com/news/business-42777804 [Accessed: 19 October 2018] 
Ha-Brookshire, J. E., Hodges, N. N. (2009) "Socially Responsible Consumer Behavior?: Exploring Used Clothing Donation Behaviour", Clothing and Textiles Research Journal, 27(3), pp. 179-196.

https://doi.org/10.1177/0887302X08327199

Henninger, C. E., Alevizou, P. J., Oates, C. J., Henninger, C. E. (2016) "What is sustainable fashion?", Journal of Fashion Marketing and Management, 20(4), pp. 400-416.

https://doi.org/10.1108/JFMM-07-2015-0052

Hlédik, E., Lógó, E. (2017) "Product Experiences and Consumer Preferences Related to the Choice of Yogurt", Periodica Polytechnica Social and Management Sciences, 25(1), pp. 64-69. https://doi.org/10.3311/PPso.9331

Holbrook, M. B. (1996) "Special Session Summary Customer Value C a Framework For Analysis and Research", NA - Advances in Consumer Research, 23, pp. 138-142.

King, S. C., Weber, A. J., Meiselman, H. L., Lv, N. (2004) "The effect of meal situation, social interaction, physical environment and choice on food acceptability", Food Quality and Preference, 15(7-8), pp. 645-653.

https://doi.org/10.1016/j.foodqual.2004.04.010

Marshall, D. W. (1995) "Food Choice and the Consumer", Blackie Academic \& Professional, London, UK, pp. 244-274.

Meiselman, H. L. (1996) "The contextual basis for food acceptance, food choice and food intake: the food, the situation and the individual", In: Meiselman, H. L., MacFie, H. J. H. (eds.) Food Choice, Acceptance and Consumption, Blackie Academic and Professional, London, UK, pp. 239-263. https://doi.org/10.1007/978-1-4613-1221-5_6
Munkácsi, N. (2018) "The Role of Knowledge-based Consumption in the Consumers' Purchase Decisions of Heating Products", Periodica Polytechnica Social and Management Sciences, 26(2), pp. 137-148. https://doi.org/10.3311/PPso.11778

Pine, B. J., Gilmore, J. H. (1999) "The Experience Economy: Work is Theatre and Every Business a Stage", Harvard Business School Press, Cambridge, MA, USA.

Rangaswamy, A., Van Bruggen, G. H. (2005) "Opportunities and challenges in multichannel marketing: An introduction to the special issue", Journal of Interactive Marketing, 19(2), pp. 5-11. https://doi.org/10.1002/dir.20037

Schifferstein, H. N. J., Hekkert, P. (2008) "Introducing Product Experience", In: Schifferstein, H. N. J., Hekkert, P. (eds.) Product Experience, London: Elsevier Science, Amsterdam, Netherlands, pp. $1-8$.

https://doi.org/10.1016/B978-008045089-6.50003-4

Stroebele, N., De Castro, J. M. (2004) "Effect of ambience on food intake and food choice", Nutrition, 20(9), pp. 821-838. https://doi.org/10.1016/j.nut.2004.05.012

Willander, J., Larsson, M. (2006) "Smell your way back to childhood: Autobiographical odor memory", Psychonomic Bulletin and Review, 13(2), pp. 240-244. https://doi.org/10.3758/BF03193837

Young, W., Hwang, K., McDonald, S., Oates, C. J. (2009) "Sustainable consumption: green consumer behaviour when purchasing products", Sustainable Development, 18(1), pp. 20-31. https://doi.org/10.1002/sd.394 